Integrated Continental-Shelf and Marginal Marine Environmental Research program: Sediments, Organisms, and Waters in New York Bight and Vicinity*

GERALD M. FRIEDMAN

Department of Geology, Rensselaer Polytechnic Institute, Troy, New York

JOHN E. SANDERS

Department of Geology, Barnard College, Columbia Jniversity, New York, N. Y.

In 1964, a program was inaugurated to study the environmental relationships among bottom sediments, microorganisms, and waters (surface, bottom, and interstitial) on the continental shelf of New York Bight (Friedman, 1966). In 1968, the scope was enlarged to include samples from marginal marine environments in Great South Bay, Long Island, and from near the mouth of the Connecticut River. We here review the accomplishments and future plans of this program. The original field work, which began in 1965, and early laboratory analyses were carried out under the sponsorship of the U.S. Office of Naval Research via Hudson Laboratories of Columbia University. These laboratories were closed on June 30, 1969, but the shelf research has been continued in the Departments of Geology at Rensselaer Polytechnic Institute and Columbia University.

Our sampling network of stations (Fig. 1), spaced at 2-mile intervals, ranks our study area among the most densely sampled sectors of any shelf area. Station locations were controlled by reference to the New York Decca Chain. In carrying out the field work we found it necessary to develop new techniques and equipment. Results to date have included chemical studies of the waters, analyses of the sediment particles, para-ecological studies of benthonic foraminifera and associated microorganisms, and $\mathrm{X}$-ray radiography of sediment cores.

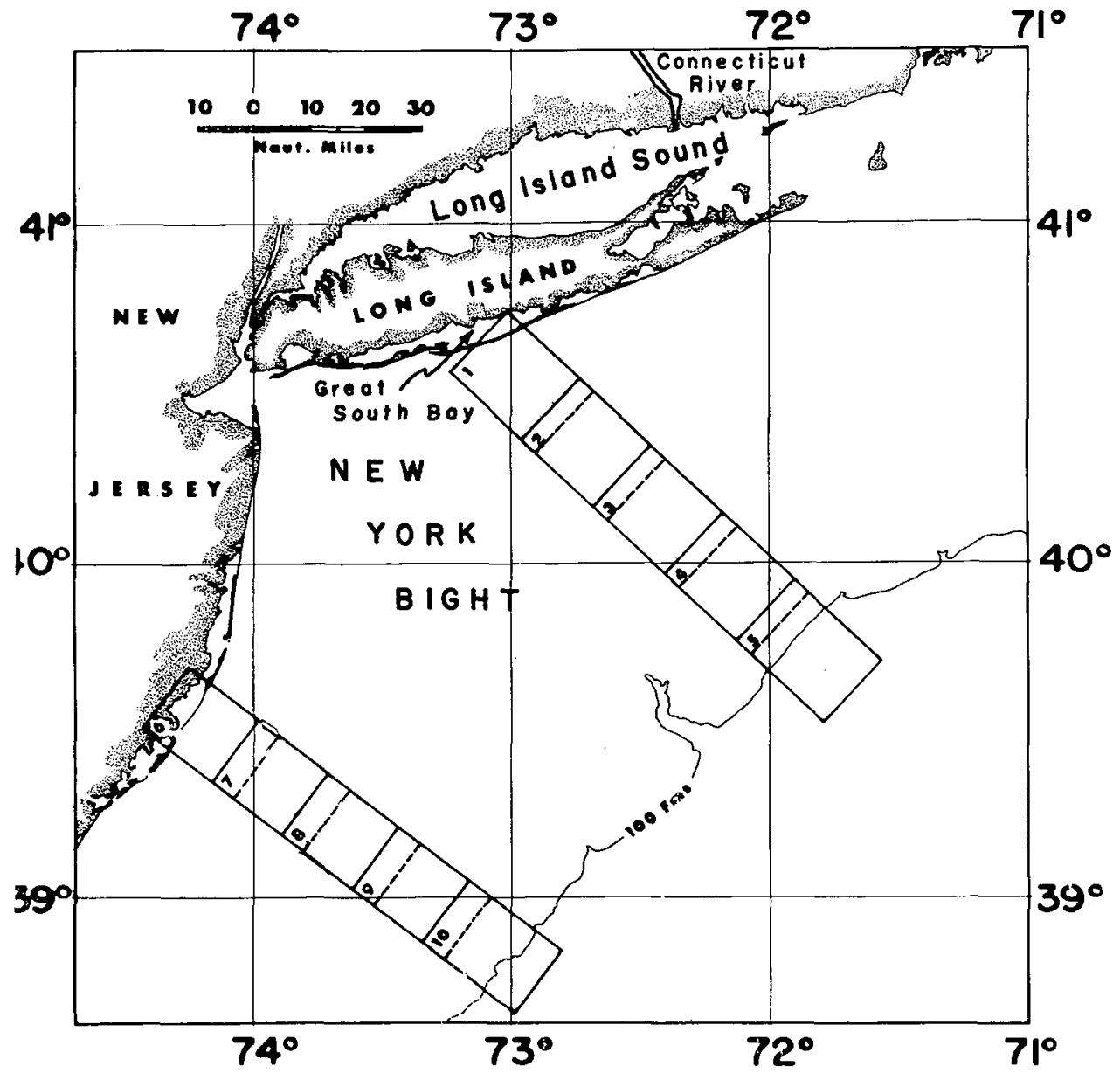

Figure 1 - Index map of shelf areas in New York Bight and nearby marginal marine areas sampled for this research program. The rectangles numbered from 1 through 10 show locations of Decca charts on a scale of 2 in. I nautical mile prepared for this research.

* Manuscript received April 22, 1970. 
The water program included collection and analysis of samples from the sea surface, from just above the water/sediment interface, and from interstitial waters at various depths down to $2 \mathrm{~m}$ within the sediment cores. Our initial study concerned stations from the open shelf (Friedman and others, 1968) (Fig. 1). Later, however, the water-sampling network was extended to include coastal environments from Great South Bay, Long Island, New York, and Long Island Sound, near the mouth of the Connecticut River (Friedman and Gavish, 1970a,b).

Within the interstitial waters, certain systematic trends have been found whose distribution spans various kinds of sediments deposited in widely contrasting environments. These systematic chemical trends include variations in the concentrations of certain dissolved cations between bottom waters and interstitial waters collected at various depths within the cores. Measured concentrations of chlorinity, $\mathrm{Ca} / \mathrm{Cl}$, and $\mathrm{Rb} / \mathrm{Cl}$ (measured on shelf samples only) in the interstitial waters increased over those in surface and bottom waters, whereas those of $\mathrm{Sr} / \mathrm{Cl}$ decreased. These trends were found in sediments ranging in particle size from clays to wellsorted sands, and which were deposited in environments both marine (open shelf) and transitional (lagoon, delta, and distal or seaward parts of estuaries). Other trends were systematic but varied with environment. For example, the $\mathrm{K} / \mathrm{Cl}$ ratio increased and the $\mathrm{Mg} / \mathrm{Cl}$ remained the same in the interstitial waters of sediment cores from the marine environment (open shelf), but both $\mathrm{K} / \mathrm{Cl}$ and $\mathrm{Mg} / \mathrm{Cl}$ ratios decreased in the interstitial waters of cores from the transitional environments. No systematic trends of chlorinity were found by comparing interstitial waters with bottom waters in tidal marshes and the proximal (landward) parts of estuaries. No increase or decrease in the $\mathrm{Li} / \mathrm{Cl}$ ratio was found in comparing bottom waters with interstitial waters in sediments of the marine environment, but the $\mathrm{Li} / \mathrm{Cl}$ ratio was higher on the inner shelf than on the outer shelf. Below the water/sediment interface in all sediments from all, environments sampled $\mathrm{pH}$ and Eh decreased (McKinney and Friedman, 1967; Friedman and others, 1968; Friedman and Gavish, 1970a, b).

One of the surprising discoveries of this study was the increase of the $\mathrm{Ca} / \mathrm{Cl}$ ratio in the interstitial waters and the decrease in the $\mathrm{Sr} / \mathrm{Cl}$ ratio over that in bottom- and in surface waters. Normally in the geochemical cycle the behaviour of strontium parallels that of calcium. The reason for this difference of behaviour of $\mathrm{Sr}$ from that of $\mathrm{Ca}$ is not known; perhaps it is related to a discriminating effect of clay minerals or of organic complexes acting as scavengers.

Future research will be directed toward possible seasonal effects and toward samples from greater depths below the water/sediment interface.

\section{Sediment Particles}

Two detailed studies of characteristics of sediment particles have been made from the samples at the water/sediment interface on the Long Island and New Jersey shelves. The Long Island shelf study has been published (McKinney and Friedman, 1969, 1970). The New Jersey shelf study is nearing completion (Frank and Friedman, in preparation).

The morphology of the Long Island shelf reflects the relict pattern of a subaerial, coastal-plain fluvial drainage system which originated during one or more lower stands of sea level. At depths. of $<35$ fathoms the sediments consist of clean sands, whereas at depths $>35$ fathoms they are muddy sands. The sharp "mud line" at about 35 fathoms results not from modern deposition but from the winnowing of a formerly more extensive relict muddy sediment. Distinctive particle-size subpopulations were separated using Hald's (1952) technique. In the sediments from the Long Island continental shelf these subpopulations correspond to the three populations described by Moss $(1962,1963)$ and by Visher $(1965, . .1969)$, which they thought resulted, respectively, from the transport processes of saltation, interstitial entrapment and/or suspension, and sliding and rolling. Using the subpopulation concept as well as statistical movement measures of the single combined size-frequency distribution, it is possible to interpret the shelf sediments as products deposited in various relict environments. Distinction is made between sediments deposited in former surf zones and those deposited by currents. Most of the sediments were deposited in shallow, nearshore environments, but many appear to have been modified by currents. Fine, winnowed sands on the inner shelf probably represent the results of reworking of a backbarrier facies by the transgressive sea (McKinney and Friedman, 1969, 1970).

In contrast to the sediments of the Long Island shelf, the sediments of the New Jersey shelf are almost entirely devoid of fine-grained particles (particles smaller than $62 \mu$ in diameter). In fact, very few sediments contain particles smaller than $125 \mu$. Those few samples with particles in the 125 - to $62-\mu$ range cluster at a depth of 20 and 40 fathoms. Such sediments are interpreted to consist of particles derived from beach-dunes of former batrier islands (Frank and Friedman, in preparation). 
Comprehensive para-ecologic (meaning analysis of the distributions of the preservable hard parts of organisms studies have been completed from samples collected across the Long Island shelf (Gevirtz, Park, and Friedman, in press). Microorganisms studied included planktonic and benthonic foraminifera, diatoms, and ostracods. The faunal study involved staining techniques to distinguish between tests of foraminifera that included living protoplasm at time of collection and tests that did not include living protoplasm at time of collection. Systematic separation and counting techniques provided numerical data that were machine-processed using the techniques of cluster analysis, ordination, and trend-surface analysis.

Nine biofacies and eleven biotopes were recognized. of these, five biofacies and nine biotopes occur on the shelf and four biofacies and two biotopes, on the upper slope. Quantitative analysis allowed us to distinguish relict faunas. These relict faunas reinforced the particle evidence that during the Holocene submergence only one protracted stillstand with respect to present sea level is 35 fathoms.

\section{Geologic Study of Cores}

Altogether 74 cores have been collected from the inner and outer shelves and from various marginal environments. These cores have been X-radiographed by Naresh Kumar using techniques developed by Baker and Friedman (1969). Further geologic analyses of these cores is contemplated in conjunction with the study of the sediments in Fire Island Inlet (Kumar and Sanders, 1970a,b).

\section{Techniques and Instruments}

Recovery of interstitial waters from sandy cores and field measurement of $\mathrm{pH}$ and $\mathrm{Eh}$ required new techniques which were developed during this program. The high permeability of the sandy cores necessitated a tight seal at the top of the cores and sampling from the bottom upwards (Sanders, Friedman, and Bennin, 1968). The insertion of the electrodes through the plastic core liner involved new techniques of drilling and of plugging the holes and of packing around the electrodes (Friedman and Kumar, 1969). Sampling the hard-packed sands of the inner and middle shelf proved to be very difficult. On the inner shelf (to depths of $120 \mathrm{ft}$.) cores were collected by a newly developed method requiring divers (Sanders, 1968). Other sampling tools built at Hudson Laboratories for this program included an explosive corer designed by Thomas Farrell and a vibrocorer. These tools never attained routinely operational status and yielded cores not containing in situ interstitial waters.

\section{Conclusions}

Traditionally geologists have studied modern environments because such studies enable them to reconstruct the environmental conditions under which ancient rocks were formed. The concern has been to apply the key geologic motto: "the present is the key to the past". However, in recent years, the impact of man's ever-increasing numbers and increasing technological sophistication upon the environment has become so large that geologic concern for environments must be reoriented. The problem now is to understand man's impact on his environment to determine what must be done to insure that the present will be the basis for a future that involves the continuing survival of man. The results obtained by this program so far provide baseline information about the modern marine environment in the outer parts of New York Bight. Such information forms the basis not only for paleoecologic studies of ancient shelf sediments, but also for comparing with possible future changes brought about by man. Our results amply justify the value of our original plan, conceived in 1964, for an integrated study of shelf sediments, microorganisms, and waters. Such an integrated approach must be followed and enlarged in future research devoted to the impact of man on the marine environment. Geologic, chemical, and biologic studies of the relationships among sediment dynamics, sediment particles, waters, and organisms bear directly on questions involving water pollution and solid waste disposal (Sanders, 1970, manuscript; Friedman, 1970). These and other subjects were discussed recently at the Symposium on water Pollution in the New York Bight sponsored by the Mayor's Oceanographic Advisory Committee on December 13, 1969. The proceedings of this symposium will be published shortly (Johnson, 1970).

\section{References cited}

BAKER, S.R. and FRIEDMAN, G.M., 1969, A non-destructive core analysis technique using $X-r a y s:$ Jour. Sedimentary Petrology, v. 39, p. 1371-1383.

FRANK, WILLIAM and FRIEDMAN, G.M., in preparation, continental-shelf sediments off central New Jersey.

FRIEDMAN, G.M., 1966, Study of continental shelf and slope on the coasts of Long Island, N.Y., and New Jersey: Maritime Sediments, v. 2, p. 2I-22. 
, 1970, Sediment-water interaction in New York Bight, in Johnson, A.A., ed., Symposium on water pollution in the Greater New York area. New York City, December 13, 1969, Gordon N. Breach, Publisher.

, FABRICAND, B.P., IMBIMBO, E.S., BREY, M.E., and SANDERS, J.E., 1968, Chemical changes in interstitial waters from continental shelf sediments: Jour. Sedimentary Petrology, v. 38, p. 1313-1319.

and GAVIGH, ELIEZER, 1970a, Chemical changes in interstitial waters from lagoonal, estuarine, tidal marsh, and deltaic environments: (abs.) Geol. Soc. America, Abstracts with Program, v. 2, p. 20-21.

1970b, Chemical changes in interstitial waters from sediments of lagoonal, deltaic, river estuarine, and saltwater marsh and cove environments: Jour. Sedimentary Petrology, v. 40 , in press.

and KUMAR, NARESH, 1969, Procedure for shipboard measurement of $\mathrm{pH}$ and th in sediment cores within plastic liners: Jour. Sedimentary Petrology, v. 38, p. 1247-1249.

GEVIRTZ, J.L., PARK, R.A., and FRIEDMAN, G.M., in press, Para-ecology of benthonic foraminifera and assorted microorganisms of the continental shelf of Long Island, New York: Jaur. Palaeontology.

HALD, A., 1952, Statistical theory, with engineering applications. New York, John Wiley and Sons, Inc., $783 \mathrm{p}$.

JOHNSON, A.A., 1970, ed., Symposium on water pollution in the Greater New York area. New York City, December 13, 1969, Gordon N. Breach, Publisher.

KUMAR, NARESH and SANDERS, J.E., 1970a, Geologic implications of migration of Fire Island Inlet: (abs.) Geol. Soc. America, Abstracts with Program, v. 2, p. 27.

, 1970b, Are basal transgressive sands chiefly inlet-filling sands?: Maritime Sediments, v. 6, n. 1, p. 12 .

MCKINNEY, T.F. and FRIEDMAN, G.M., 1967, Geochemistry of seawater above and below the water/ sediment interface on the New York and New Jersey continental shelves: (abs.) Geol. Soc. America, Spec. Paper No. 101, p. 268-269.

MCKINNEY, T.F., 1969, Sediments of the continental shelf off Long Island, New York: (abs.) Geol. Soc. America, Abstracts with Program, part 1, p. 40.

and FRIEDMAN, G.M., 1970, Continental shelf sediments of Long Island, New York: Jour. Sedimentary Petrology, v. 40, p. 213-248.

MOSS, A.J., 1962, 1963, The physical nature of common sandy and pebbly deposits: Part I: Am. Jour. Sci., v. 260, p. 337-373. Part II: v. 261, p. 297-343.

SANDERS, J.E., 1968, Diver-operated simple hand tools for coring nearshore sands: Jour. Sedimentary petralogy, v. 38, p. 1381-1386.

, 1970, Physical aspects of the New York Bight and estuaries: coastal-zone geology, in Johnson, A.A., ed., Symposium on water pollution in the Greater New York area. New York City, December 13, 1969, Gordon and Breach, Publisher.

- manuscript, Relationships of geology to pollution problems, New York City area, 13 manuscript pages (to be submitted to Jour. Geol. Education).

, FRIEDMAN, G.M., and BENNIN, R.S., 1968, Procedure for recovering bottom and interstitial waters from cores of sandy sediments from the continental shelf: Jour. Sedimentary Petrology, v. 38, p. 683-684.

VISHER, G.S., 1965, Fluvial processes as interpreted from ancient and recent fluvial deposits, p. 116-132 in Middleton, G.V., editor, Primary sedimentary structures and their hydrodynamic interpretation: Tulsa, Okla., Soc. Econ. Paleontologists and Mineralogists, Spec. Pub. 12, 265 p.

, 1969, Grain size distributions and depositional processes: Jour. Sedimentary Petrology, v. 39, p. 1074-1106. 